\title{
Size matters: Development and cooperation of municipalities in the Brno metropolitan area (Czech Republic)
}

\author{
Josef KUNC, Petr TONEV, Markéta NOVOTNÁ, Petr ŠAŠINKA, \\ Zdeněk DVOŘÁK, Soňa RASZKOVÁ, Aneta KRAJÍČKOVÁ
}

\begin{abstract}
The Czech Republic is typical for its fragmented settlement structure with a high number of small self-governing municipalities. Such a distinction causes many problems, including a non-effective way of their management. Even though various integration methods have already been applied in Europe for several decades, the Czech Republic, due to its historical development influenced by the period of communism, is still looking for intermunicipal cooperation opportunities at a higher (metropolitan) level. The presented text aims to evaluate a municipalities' willingness to cooperate on particular activities and participate in selected topics on strategic and spatial planning at a metropolitan level. Their willingness is analysed according to the population size category of municipalities so that diverse approaches towards the willingness to cooperate could be identified for municipalities in different categories. The results are demonstrated by the example of the Brno Metropolitan Area, which is regarded to be a leader in the development of inter-municipal cooperation at a metropolitan level in the Czech Republic. The results were obtained from a questionnaire survey carried out with the mayors of the Brno metropolitan area in 2020. From a total of 184 municipalities, 175 municipalities took part in the questionnaire survey. Thus, the return was $95 \%$. The results show that the assumption of the importance of the municipality population size is significant when making decisions about future development and cooperation within a metropolitan area. Although most municipalities in all size categories consider it useful to engage in cooperation and solve selected topics together at a metropolitan level, the municipalities in the smallest size categories of up to 1,000 inhabitants had a significantly lower proportion of very positive responses (definitely yes) than municipalities in the other categories. This fact may be attributed to the specific development of the Czech settlement system and the so-called historical memory of the residents from small municipalities during the directive merger in the 1970s and 1980s.
\end{abstract}

Keywords: cooperation, spatial planning, metropolitan areas, Czech Republic

\section{Introduction}

Post-socialist Central European countries are currently facing several economic and social challenges, at the forefront of which stand large population cities with over 250,000 inhabitants referred to, according to the so-called urban centre, as L, XL and XXL (EC-OECB 2012). They are the places where most of the population is concentrated, and at the same time, the main places of origin and further application of new economic and social processes and are the places from where innovations and lifestyle change are spreading out. The cities and towns are economic and organisation cores of the areas whose centripetal bonds influence daily running and are referred to as functional urban regions (daily urban systems), urban agglomeration or metropolitan areas (Stanilov 2007, Viturka et al. 2017, Drummond and Young 2020).

DOI: https://doi.org/10.33542/GC2021-2-06 
The term metropolitan area/metropolitan region or alike is predominantly used in the professional geographic and urbanistic literature describing the city and its hinterland, as no unanimously accepted definition of such term exists. Although these concepts are perceived differently in historical development and by many authors (Berry 1970, Gibson 1987, Hall 2007, Boix et al. 2012 and many others) and important world or European organisations (GEMACA 1996, 2006, ÖIR 2006, EC-OECD 2012), it is not decisive for the purposes of our contribution, so that we will perceive and approach them in the same way.

Our contribution evaluates selected results obtained from the survey conducted in the Brno metropolitan area (BMA). This paper aims, based on the criteria of municipality population size, to analyse, interpret and evaluate selected results of the survey carried out with representatives of the municipalities located in the BMA. The questions focused mainly on the willingness of municipalities to engage in cooperation on activities that could be addressed jointly at a metropolitan level (drought, erosion, flood control measures, waste management, residential and commercial construction). Our research hypothesis lies in the assumption that the size of the municipality matters in decision-making processes. In other words, municipalities of different sizes have different approaches to a willingness to cooperate.

\section{Theoretical background}

\section{Metropolitan areas in post-socialist countries and in the Czech Republic}

There are several differences in individual European cities, mainly due to differences in their socio-cultural environment. This environment was developed in the second half of the twentieth century with the influence of specific factors, which through historical memory still have an impact on the formation of functional urban areas (Tosics 2005, Šašinka and Zvara 2014, Šašinka et al. 2019, Kunc et al. 2020). As far as Central and Eastern Europe are concerned, the origin and the development of metropolitan areas were affected by the post-war arrival of communism that partially inhibited the natural development of metropolitan areas due to the central planning end economic and social equalisation. The emphasis on heavy industry and, to a certain extent, "artificial" system of centres of rural settlements accentuated by the polarisation of the capital city and the rest of the country (Lang 2015) contrasted with the deindustrialisation and the development of the tertiary sector in the western European countries (Kunc et al. 2018).

The entire organisation of the society of the former socialist countries of central and Eastern Europe went through a lot of changes that also concerned the development of metropolitan areas (Dostál and Hampl 2002, Harloe 2008, Aligica and Evans 2009, or most recently also Mihuła and Kaczmarek 2017, Bański et al. 2018 and others). As Čermák et al. (2009) state, even in these countries, some trends and processes that formed the urban systems in the western countries could be fully employed and developed, yet with a certain delay and deformation. The processes of liberalisation, privatisation, restitution and the gradual opening to foreign investors became the tools of socio-economic changes. The metropolitan areas now play a much more important part in the socio-economic development of the European post-socialist countries than they used to in the past.

It is not a coincidence that the concept of the discussed metropolitan cooperation and planning appears in the professional literature focused on the post-socialist Central European space. Moreover, we may observe that in plenty of Western European metropolitan areas, these new forms of cooperation and governance were not only set (Salet and Thornley 2007) but are successfully in operation (Wilks-Heeg et al. 2002, Harrison and Hoyler 2014, Šašinka et al. 2019, Kunc et al. 2020).

Benedek (2016) and Török (2015) try to assess in their studies the formation of urban growth poles as the key elements of the new regional policy in Romania. The authors are also drawing attention to the fact that although the conceptional debate on urban or metropolitan regions started relatively late in the EU, it played an important role in spatial planning 
and research. A similar topic is approached by Viturka et al. (2017) exampled by the case of the Czech Republic, Jacobs (2013) and Šveda et al. (2016) exampled by the case of Slovakia or Kebza (2018) and Bański et al. (2018) exampled by the case of Poland as well as Europe in general, while they both highlight an increasing specialisation of the regional economy, as well as the growing differences between the metropolitan areas and peripheries. Although this fact contradicts the cohesion policy of the EU as well as the equalising of the regional differences (Lang 2015), we are inclined to think that the differences will deepen in favour of the metropolitan areas, and it will contribute to the strengthening of their importance and the subsequent necessity to administer them.

Metropolisation of the Czech Republic area was (and still is) fundamentally determined by specific features from the period of communism: deeper geographic inequality of settlement and resort hierarchy (massive directive merger of municipalities during the 1970s and 1980s), the concentration of population into heavy industry areas, or slowing down the development of the largest centres in the country, and subsequent decline of population in large cities. These particularities overshadowed the processes of forming natural functional urban regions (Hampl 1987, Hampl and Müller 1996, Čermák et al. 2009). They began to be formed only in the transformation period, with a delay, compared to Western countries, but more rapidly (Musil 2003).

In the first half of the 1980s, the boundaries of the so-called Settlement Region Agglomerations and Urban Regions were established in the territory of the county by the then socialist planners. However, they never fulfilled their function and were formally cancelled ten years later. In 1989, there is a gradual return to the natural development trajectory which was going on in the Western part of Europe. However, the new situation remained without a proper response, and since the beginning of the 1990s, a metropolitan planning, political and academic vacuum prevailed. Yet, in the last two decades, the situation has changed, experts are showing more interest in the study of metropolitan areas, and not only approaches and methods for defining them are coming to the forefront (e.g. Kostelecký and Čermák 2004, Sýkora and Mulíček 2009, Klapka et al. 2016, Tonev et al. 2017, Ženka et al. 2017) but also activities connected with the development of metropolitan planning, cooperation and industrialisation of metropolitan areas are appearing (primarily from the part of planning practice) (Šašinka and Zvara 2014, Šašinka et al. 2019, Kunc et al. 2020).

A new period of spatial organisation and planning at a metropolitan level opened in the Czech Republic at the beginning of the last decade in connection with a new tool for the realisation of territory dimension in metropolitan areas/agglomerations of national importance, the socalled integrated territory investments (ITI). It is a new tool for the application of an integrated approach by using European Structural and Investments Funds. ITI tool is determined for metropolitan areas/settlement agglomerations with a concentration of over 300,000 inhabitants, such as metropolitan areas of Prague, Brno, Ostrava, Plzeň, and settlement agglomerations of Ústí nad Labem - Chomutov, Olomouc and Hradec Králové - Pardubice agglomerations in compliance with the Regional Development Strategy of the Czech Republic 2014-2020 and 2021+ (Ministry of Regional Development of the Czech Republic 2021).

The transformation period can be described as a sort of cleansing process followed by stagnation or further decline of medium and small size centres in the following decade. The most dynamic development was evident in the large natural centres, which began to attract commuters from further afield. Since the mid of the 1990s, the process of suburbanisation, which has a reverse vector of impact, has also been going on. Two-way functional interaction between Brno and its hinterland has been further intensified and taken on larger spatial dimensions, the growing position of Brno as a centre of the region clearly stands out, resulting in ever-growing polarisation of the Brno metropolitan area (Tonev et al. 2017).

In this respect, the need for a certain formalisation of cooperation has been gradually initiated by the core city (bottom-up approach) in the BMA after 2010, primarily in the context of its substantive level - addressing particular topics such as sustainable mobility, accessibility, combating drought, revitalisation, waste management, coordination of residential and commercial 
construction, a school system or ageing of the population. However, so far it has just been about ad-hoc solutions lacking a conceptual approach, which was and has still been limited by a non-existing anchoring of the institutional level of metropolitan cooperation in the Czech spatial planning system (Šašinka et al. 2019, Kunc et al. 2020).

\section{Basics of metropolitan cooperation}

The coordination and cooperation at a level of metropolitan areas are necessary to solve large urban challenges in the present days (Heeg et al. 2003). These activities often require systemic and targeted public sector intervention to be effective (top-down and bottom-up approach) within the context of determining objectives of the metropolitan policy and its tools (integration intervention approach) (Brezzi et al. 2015).

Within the context of the basic convergent or divergent theories of regional development, the objectives of the regional metropolitan (regional) policy can focus on decreasing or increasing changes between the regions - they can also be viewed through the paradigm of endogenous or exogenous perspectives (solution inside or outside the metropolitan region). However, in practice, we almost always encounter the combination of the approaches stated above (Hall 2007). Moreover, it is necessary to realize that the desired regional development (objective) is becoming increasingly subjective, as it depends on the value orientation of stakeholders operating in a metropolitan area (citizens, local authorities, etc.). Here, the need to find consensus in joint planned particular objectives and activities is far more important (Cox 1995), which also determines the set of selected tools in the development of metropolitan areas (Klok 1995).

An important aspect of the metropolitan policy is the question of its spatial conception and view (Kloosterman and Musterd 2001), or more precisely, the territorial level of its implementation (Feiock 2009). At the national level, a significant trend in regional policy is its interconnection with other state policies. However, some authors point to the ever-decreasing role of the national level in regional development (so-called "de-nationalisation" - Heeg et al. 2003). Ostrom (2010) adds that locally evolved self-governing institutions that are adapted to specific local circumstances may provide more effective resolution of collective action problems than central intervention in many circumstances. This approach builds on the New Regionalism focuses on the interconnectedness of metropolitan regions by emphasizing voluntary cooperation, informal networking, and integration (Paasi 2002, Groth and Corijn 2005) rather than top-down mechanisms to promote metropolitan coordination and cooperation among the fragmented stakeholders (Katz 2000, Paasi 2012), and in practice, these approaches often interact.

The setting up of metropolitan cooperation among municipalities could be institutionalised through "metropolitan association of municipalities" which may be based on the idea of the existing "voluntary association of municipalities". This territorial framework has a long-term legislative basis in the Czech Republic. A combination of a "registered institute" or a newly established legal entity "sui generis" is another option for institutionalisation. When clarifying the competencies with the regional bodies and the administrative district of a municipality with extended powers, it is possible to consider the metropolitan association (functional territory of the agglomeration) as a new form of self-governance.

\section{Materials and methods}

Currently, the Brno metropolitan area is a leader in the planning issues and development of intermunicipal metropolitan cooperation in the Czech Republic. The spatial determination from 2014 (Mulíček et al. 2013) is followed with a new one from 2020 (Ouředníček et al. 2020), and the BMA has stabilised at 184 municipalities, 700,000 inhabitants and an area of almost 2,000 square kilometres. The BMA, like other metropolitan areas in the Czech Republic, does not yet have legislative support in the Czech public administration system. The definition of these areas primarily serves as a basis for the implementation of regional policy through the Regional Development Strategy of the Czech Republic 2021+. Their definition will continue 
to be important also for the creation and implementation of the Integrated Development Strategy of the Brno Metropolitan Area 21+ and for the use of the ITI territorial tool.

The methodological basis of the research was a questionnaire survey carried out by the mayors of the Brno metropolitan area municipalities in 2020. Concerning a methodologically similar survey from 2017, there was no need to perform trial tests (pre-test); representatives of municipalities were made familiar with the submitted questions. The survey was performed under the auspices of the Brno Municipal Authority, ITI Administration Department and metropolitan cooperation. All municipalities were reached out, and 175 questionnaires were returned after being urged by phone or e-mail. Thus, the return rate was $95 \%$. The obtained data were processed in Microsoft Excel and ArcGIS. From our own experience and review of scientific literature and different case studies, such unique research in terms of scope and representativeness has not been realised yet in any other metropolitan area of the Czech Republic and Central Europe.

As it was already stated above, more than 6,258 self-governing municipalities (to the year 2021) in the Czech Republic cause spatial, administrative, and executive fragmentation. As shown in Table 1, the smallest municipalities (of up to 500 inhabitants) represent almost 55\% out of all municipalities, and $8 \%$ of the Czech Republic citizens live there. Municipalities of up to two thousand inhabitants represent almost $90 \%$ of all municipalities, with a proportion of the population of $27 \%$. Compared to the rest of the Czech Republic, the Brno metropolitan area has a completely different settlement structure. Only $16 \%$ of municipalities are included in the lowest category (up to 500 inhabitants) with an "insignificant" $1.5 \%$ of the BMA population. All other categories have a significantly higher share of municipalities. Generally, we may conclude that the BMA settlement structure consists of larger municipalities, in terms of population, than is the country average.

Tab. 1. Share of municipalities and inhabitants in size groups of municipalities in the Czech Republic and the BMA (January 2021)

\begin{tabular}{|c|c|c|c|c|c|c|}
\hline & \multicolumn{6}{|c|}{ Size category of a municipality } \\
\hline & $\begin{array}{l}\text { Up to } \\
499\end{array}$ & $\begin{array}{c}500 \\
-999\end{array}$ & $\begin{array}{c}1,000 \\
-1,999\end{array}$ & $\begin{array}{c}2,000 \\
-4,999\end{array}$ & $\begin{array}{c}5,000 \\
-24,999\end{array}$ & $\begin{array}{c}25,000 \\
\text { and more }\end{array}$ \\
\hline \multicolumn{7}{|l|}{ Czech Republic } \\
\hline Share of municipalities in the total (\%) & 54.2 & 21.9 & 12.5 & 7.0 & 3.7 & 0.3 \\
\hline Share of inhabitants in the total (\%) & 7.8 & 9.1 & 10.2 & 12.5 & 22.4 & 38.2 \\
\hline \multicolumn{7}{|l|}{ Brno Metropolitan Area } \\
\hline Share of municipalities in the total (\%) & 16.3 & 37.0 & 25.0 & 14.7 & 6.5 & 0.5 \\
\hline Share of inhabitants in the total (\%) & 1.5 & 7.4 & 8.9 & 11.3 & 16.4 & 54.4 \\
\hline
\end{tabular}

Source: Czech Statistical Office (2021)

In our paper, we have focused on selected questions that were put in confrontation with size categories of municipalities. The size category was considered to be the main hierarchical and methodological criterion. Based on previous research experience (Šveda et al. 2016, Ženka et al. 2017, Šašinka et al. 2019, Šilhan and Kunc 2020, Kunc et al. 2020), we assumed that the municipality population size, together with the distance from the core city of a metropolitan area, is one of the basic distinguishing criteria in decision-making processes, and therefore, the answers will differ for various size categories. At first, the analysed questions were to find out whether the municipalities are willing to take part in strategic and spatial planning and cooperation within the BMA. Another question dealt with particular topics, the solution of which would be more effective if addressed jointly at the metropolitan level. Typically, it is waste management, flood protection, combating drought and erosion, residential and commercial construction, etc. It was just the potential development of localities or suggested housing areas and production/commercial facilities that had become the subject matter of deeper analyses. The mentioned size of the municipality, or size category within the BMA, became the decisive variance criterion. 


\section{Results}

The input to the analyses was the question heading towards the effectiveness of addressing jointly, at a metropolitan level, selected topics of strategic and spatial planning. Municipalities of all size categories showed a positive response to this fundamental activity; in all instances, it overcame the limit of $80 \%$. The highest proportion of positive responses was recorded with size categories of 1,000-1,999 and 5,000 or more inhabitants. However, this fact could have also been caused due to a very high level of discipline while completing the questionnaire, which accompanied these categories throughout the whole survey (see Table 2). The following question dealt with a willingness to really get involved in the given cooperation. Although it is still an informal commitment, it is possible to accept positive responses with a higher argumentation weight. The highly positive answers could also be caused by a broader concept of the introductory question, which, however, does not reduce the awareness and positive attitude of the municipalities in the BMA to possible cooperation.

The response "definitely yes" gained a higher share as the size category of municipalities increased, whereas the difference between the municipalities of up to 500 inhabitants $(33.3 \%)$ and 5,000 or more inhabitants $(83.3 \%)$ was noticeable. Table 3 clearly shows a very low share of strongly negative responses with all size categories, which demonstrates a positive assumption for future cooperation.

Tab. 2. Will it be effective to address selected topics of strategic and spatial planning within the Brno metropolitan area jointly at a metropolitan level in the future?

\begin{tabular}{l|c|cccc}
\hline \multirow{2}{*}{$\begin{array}{l}\text { Municipality category } \\
\text { according to the } \\
\text { number of inhabitants }\end{array}$} & \multirow{2}{*}{$\begin{array}{c}\text { Number of } \\
\text { municipalities }\end{array}$} & Yes & No & Not completed & In total \\
\cline { 3 - 6 } & & \multicolumn{4}{|c}{$\%$} \\
\hline Up to 500 & 30 & 83.3 & 6.7 & 10.0 & 100.0 \\
$500-999$ & 68 & 83.8 & 4.4 & 11.8 & 100.0 \\
$1,000-1,999$ & 46 & 95.7 & 2.1 & 2.2 & 100.0 \\
$2,000-4,999$ & 27 & 81.5 & 11.1 & 7.4 & 100.0 \\
5,000 and more & 12 & 91.7 & 8.3 & 0.0 & 100.0 \\
In total & 183 & 86.9 & 5.5 & 7.7 & 100.0 \\
\hline
\end{tabular}

Source: Own elaboration

Tab. 3. Are you willing to get your municipality involved in this cooperation within MBA?

\begin{tabular}{l|c|ccccc}
\hline $\begin{array}{l}\text { Municipality category } \\
\text { according to the }\end{array}$ & \multirow{2}{*}{$\begin{array}{c}\text { Number of } \\
\text { nunicipalities }\end{array}$} & $\begin{array}{c}\text { Definitely } \\
\text { yes }\end{array}$ & $\begin{array}{c}\text { Rather } \\
\text { yes }\end{array}$ & $\begin{array}{c}\text { Definitely } \\
\text { no }\end{array}$ & $\begin{array}{c}\text { Not } \\
\text { completed }\end{array}$ & In total \\
\cline { 3 - 7 } numbitants & 30 & 33.3 & 56.7 & 6.7 & 3.3 & 100.0 \\
\hline Up to 500 & 68 & 26.5 & 61.8 & 4.4 & 7.4 & 100.0 \\
$500-999$ & 46 & 52.2 & 43.5 & 2.1 & 2.2 & 100.0 \\
1,000-1,999 & 27 & 51.9 & 37.0 & 7.4 & 3.7 & 100.0 \\
$2,000-4,999$ & 12 & 83.3 & 8.3 & 8.3 & 0.0 & 100.0 \\
5,000 and more & 183 & 41.5 & 49.2 & 4.9 & 4.4 & 100.0 \\
\hline In total & &
\end{tabular}

Source: Own elaboration

The question supporting the emergence of a metropolitan spatial plan that would address the topics related to the spatial impact of the overall majority of municipalities (excluding the category of 5,000 and more inhabitants) "took the respondents by surprise", and they were not able to assess such activity. For the smallest municipalities, it was three-fifths, which was the highest value. If the municipalities had a positive response, then the smallest municipalities had the lowest support, while it increased with the growing population (see Table 4). 
Tab. 4. Would you support the emergence of a spatial plan at the BMA level which would address particular topics with spatial impact?

\begin{tabular}{l|c|ccccc}
\hline $\begin{array}{l}\text { Municipality category } \\
\text { according to the } \\
\text { number of inhabitants }\end{array}$ & \multirow{2}{*}{$\begin{array}{c}\text { Number of } \\
\text { municipalities }\end{array}$} & Yes & No & $\begin{array}{c}\text { I'm not able } \\
\text { to assess }\end{array}$ & $\begin{array}{c}\text { Not } \\
\text { completed }\end{array}$ & In total \\
\cline { 3 - 7 } & & \multicolumn{5}{|c}{$\%$} \\
\hline Up to 500 & 30 & 23.3 & 6.7 & 60.0 & 10.0 & 100.0 \\
$500-999$ & 68 & 27.9 & 7.4 & 52.9 & 11.8 & 100.0 \\
$1,000-1,999$ & 46 & 39.1 & 4.3 & 54.3 & 2.2 & 100.0 \\
$2,000-4,999$ & 27 & 37.0 & 0.0 & 55.6 & 7.4 & 100.0 \\
5,000 and more & 12 & 41.7 & 16.7 & 41.7 & 0.0 & 100.0 \\
In total & 183 & 32.2 & 6.0 & 54.1 & 7.7 & 100.0 \\
\hline
\end{tabular}

Source: Own elaboration

Furthermore, we were asking about spatial plans of municipalities and potential development of residential localities and new job positions determined in them. As for the residential localities (or mixed housing areas), the limits of small municipalities in terms of population of up to 1,000 inhabitants became apparent, out of which the majority may offer a new residential capacity for up to 200 inhabitants; due to economic (and often also spatial) reasons, they cannot afford a higher volume of investments to be put into housing. It logically follows that with the growing size category, the municipalities have more options to offer development localities for housing with larger capacity. Three-quarters (nine municipalities) with more than 5,000 inhabitants have included possibilities of new flats construction for more than 1,000 inhabitants (see Table 5) in their spatial plan. Figure 1 (below) provides data depicted in space. It is evident that apart from the large towns (such as Vyškov, Ivančice or Tišnov), the most attractive localities in terms of housing, besides metropolitan Brno, include large towns with great commuting accessibility and infrastructure facilities (such as Kuřim, Šlapanice, Slavkov u Brna, Rousínov and Pohořelice), as well as the smaller towns (such as Rajhrad, Klobouky u Brna or Ořechov).

Tab. 5. What capacity of potential "development localities" for housing is included in the spatial plan of your municipality?

\begin{tabular}{l|rrrrrrr}
\hline \multirow{2}{*}{$\begin{array}{l}\text { Municipality category } \\
\text { according to the num- } \\
\text { ber of inhabitants }\end{array}$} & \multicolumn{7}{|c}{ Capacity for housing (number of inhabitants) } \\
\cline { 2 - 8 } & Up to $\mathbf{2 0 0}$ & $\mathbf{2 0 1 - 5 0 0}$ & $\mathbf{5 0 1 - 1 , 0 0 0}$ & Over 1,000 & None & Not completed & In total \\
\hline Up to 500 & 80.0 & 3.3 & 0.0 & 0.0 & 6.7 & 10.0 & 100.0 \\
$500-999$ & 77.9 & 8.8 & 0.0 & 1.5 & 0.0 & 11.8 & 100.0 \\
$1,000-1,999$ & 47.8 & 30.4 & 4.3 & 2.2 & 13.0 & 2.2 & 100.0 \\
$2,000-4,999$ & 18.5 & 44.4 & 11.1 & 11.1 & 7.4 & 7.4 & 100.0 \\
5,000 and more & 8.3 & 0.0 & 16.7 & 75.0 & 0.0 & 0.0 & 100.0 \\
In total & 57.4 & 18.0 & 3.8 & 7.7 & 5.5 & 7.7 & 100.0 \\
\hline
\end{tabular}

Source: Own elaboration

Development localities included in the spatial plan determined for new job positions are distributed mostly into two edge intervals; the lowest category of up to 200 employees or there are none. As expected, the handicap of the smallest municipalities of up to 500 inhabitants that are not able to put investments in the creation of new job positions due to their economic situation was even more evident in this case (see Table 6). Again, Figure 1 offers a space overview of the BMA where we can see localities with the largest development potential in terms of employment (more than 1,000 new job positions). These are municipalities and cities with 2,000 and more inhabitants where large industrial zones or production and distribution parks have already been established - Kuřim, Šlapanice, Pohořelice, Ořechov, and somewhat surprisingly, also Oslavany affected by the black coal mining in the past. 
Tab. 6. What capacity of potential "development localities" for new job positions has been included in the spatial plan of your municipality?

\begin{tabular}{l|ccccccc}
\hline $\begin{array}{l}\text { Municipality category } \\
\text { according to the }\end{array}$ & \multicolumn{6}{|c}{ Capacity for new job positions (number of employees) } \\
\cline { 2 - 8 } number of inhabitants & Up to $\mathbf{2 0 0}$ & $\mathbf{2 0 1 - 5 0 0}$ & $\mathbf{5 0 1 - 1 , 0 0 0}$ & Over 1,000 & None & Not & In total \\
\hline Up to 500 & 20.0 & 0.0 & 0.0 & 0.0 & 70.0 & 10.0 & 100.0 \\
$500-999$ & 48.5 & 1.5 & 0.0 & 0.0 & 38.2 & 11.8 & 100.0 \\
$1,000-1,999$ & 45.7 & 10.9 & 0.0 & 0.0 & 41.3 & 2.2 & 100.0 \\
$2,000-4,999$ & 51.9 & 11.1 & 0.0 & 7.4 & 22.2 & 7.4 & 100.0 \\
5,000 and more & 58.3 & 16.7 & 0.0 & 25.0 & 0.0 & 0.0 & 100.0 \\
In total & 44.3 & 6.0 & 0.0 & 2.7 & 39.3 & 7.7 & 100.0 \\
\hline
\end{tabular}

Source: Own elaboration

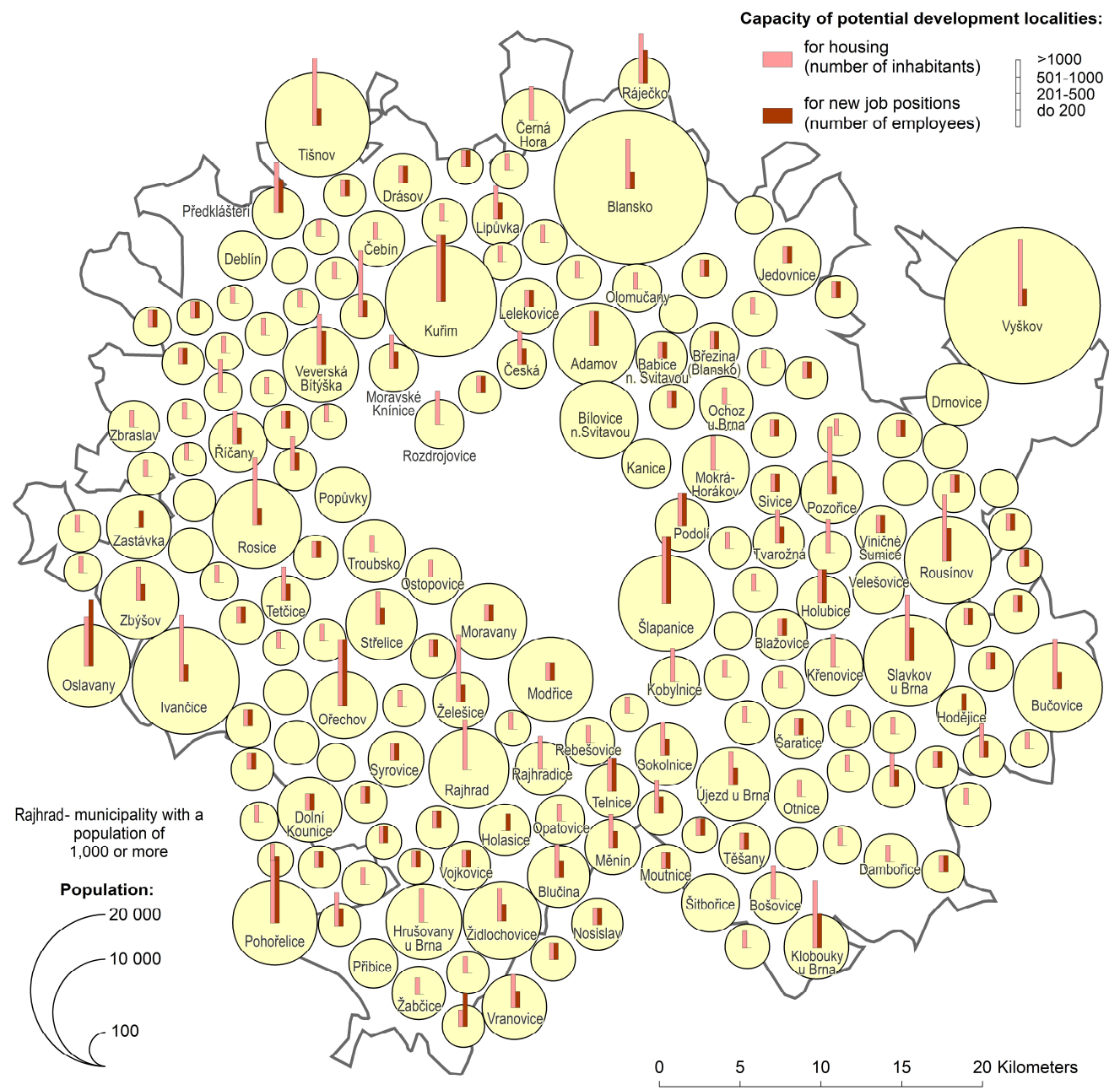

Fig. 1. Capacities of development localities in municipalities of the Brno Metropolitan Area Source: Own elaboration 

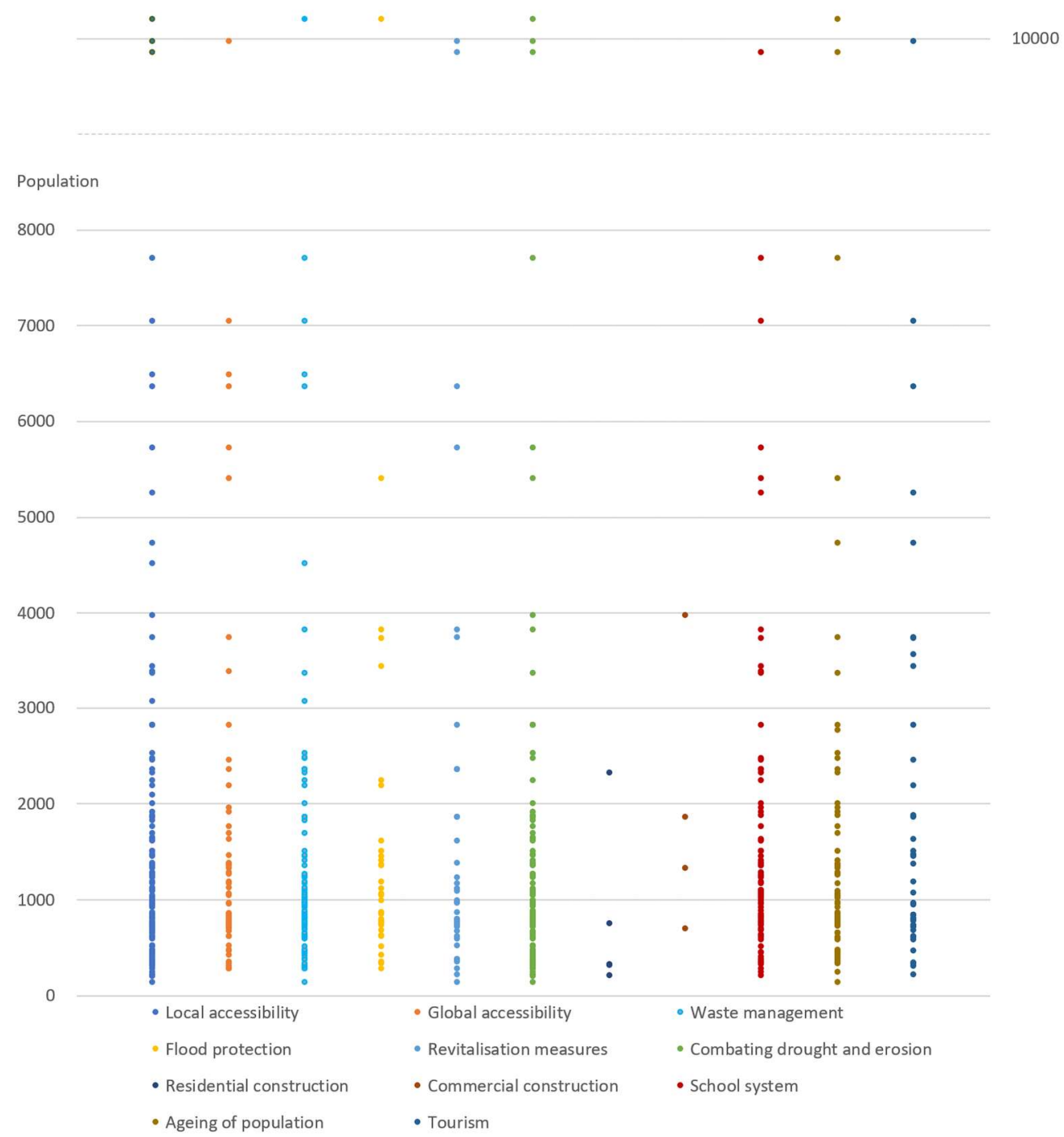

Fig. 2. Purposeful topics for a unified solution at the metropolitan level; Source: Own elaboration; Note: Up to five answers could be marked

Fig. 2 represents the topics the municipalities wish to address jointly at the metropolitan level. The smallest municipalities in terms of population (also less than 200 inhabitants) are interested in the search for joint solutions related to the topics with a higher share of public interest - local accessibility, waste management, revitalisation measures, combating drought and erosion, as well as the school system, ageing of population and tourism. On the other side of a figurative ladder, there is a "private sphere" as analysed above, in particular, residential and commercial construction which the municipalities do not wish to coordinate and address jointly. 


\section{Conclusions}

The fundamental aspect of our survey was an assumption that the municipality size in terms of population is important in decision-making processes on future development, strategic planning, and cooperation within the metropolitan area. Thus, the size matters. This assumption has proved to be correct based on a number of questions and responses. On the other hand, the statute of the town or village (mostly formally derived from a larger population) was not a significant differentiation factor. Within the discussion, it is necessary to note that a fragmented settlement structure of the Czech Republic with a large number of very small municipalities (within Europe, the situation is similar only in Slovakia and France) basically makes it difficult to bring up theoretical and realistic options of a regional (e.g. metropolitan) cooperation. Currently, the Brno metropolitan area includes 184 municipalities (700,000 inhabitants), out of which 16\% belong to the smallest size category of up to 500 inhabitants (54\% in the Czech Republic) and $37 \%$ belong to the category of 500-999 inhabitants (22\% in the Czech Republic). In particular, a significantly lower share of the smallest municipalities within the BMA, compared to the country average, can have a slightly positive impact on the future activities carried out jointly.

Another positive finding is the fact that most municipalities $(80 \%)$ of all size categories find it useful to address jointly, at a metropolitan level, selected topics of strategic and spatial planning. A willingness to get engaged in the given cooperation had among the BMA municipalities also a high response rate - responses "definitely yes" or "rather yes" have also been recorded with a large majority of municipalities. However, the smallest size category municipalities (up to 1,000 inhabitants) had a significantly lower share of very positive responses ("definitely yes") than the municipalities in other size categories. The specific development of the Czech spatial system and historical memory of the small municipalities' representatives (directive merger in the 1970s and 1980s) is evident here; thus, also respect to any joint activities at the level of a higher administrative unit that would contribute to the loss of independence (Šašinka et al. 2019, Kunc et al. 2020).

According to the municipalities' representatives, the emergence of a metropolitan spatial plan and its support is a complicated issue, and they were not able to respond to the question positively, neither negatively. If the municipalities provided a positive response, the lowest support was found with the smallest municipalities, in terms of population, and it was increasing with the growing number of populations. Determining the potential development localities for housing and new job opportunities in the spatial plan is limiting for small municipalities of up to 1,000 inhabitants, mostly due to economic (and also spatial) reasons. It is more difficult for all size categories of municipalities to consider supporting and developing employment areas rather than housing ones, whereas, for the smallest municipalities it is more or less unfeasible.

It is also clear from the research results that activities and efforts of the core metropolitan city of Brno for joint solutions of selected topics at the metropolitan level are not always met with a similar approach of other (smaller) municipalities and towns within the BMA. The municipalities are more willing to cooperate within such topics that contain a particular public interest (local accessibility, waste management, revitalisation measures, combating drought and erosion, as well as a school system, ageing of the population, etc.). On the contrary, in terms of residential and commercial construction with the aim to create new job positions, the municipalities within the BMA are not able to find a joint approach.

Both the historical specifics of the development of the Czech Republic settlement system and the existing economic (and also spatial) possibilities connected with the population size of the municipalities are reflected in the subjective perception of the benefits of joint activities and solutions to common issues at the metropolitan level by individual municipalities. Based on the results, further research could focus on defining and specifying particular frameworks of metropolitan cooperation (simply stated - a metropolitan association expanding and legislatively following on from established voluntary association of municipalities), which could be applied not only in the Czech environment but also in other post-socialist countries with many specific features originating from the common historical development. 


\section{References}

ALIGICA, P. D., EVANS, A. 2009: The Neoliberal Revolution in Eastern Europe: Economic Ideas in the Transition from Communism ( $1^{\text {st }}$ edition). Cheltenham (Edward Elgar Publishing).

BAŃSKI, J., DEGÓRSKI, M., KOMORNICKI, T., ŚLESZYŃSKI, P. 2018: The delimitation of areas of strategic intervention in Poland: A methodological trial and its results. Moravian Geographical Reports, 26(2), 84-94. DOI: https://doi.org/10.2478/mgr-2018-0007.

BENEDEK, J. 2016: The Role of Urban Growth Poles in Regional Policy: The Romanian Case. Procedia - Social and Behavioral Science, 223, 285-290.

BERRY, B. J. L., GOHEEN, P. G., GOLDSTEIN, H. 1970: Metropolitan Area Definition: A Reevaluation of Concept and Statistical Practice. In Berry, B. J. L., Horton, F. E. eds. Geographical Perspectives of Urban System. New Jersey (Prentice-Hall).

BOIX, R., VENERI, P., ALMENAR, V. 2012: Polycentric Metropolitan Areas in Europe: Towards a Unified Proposal of Delimitation. In Vázquez, E. F., Morollon, F. R. eds. Defining the Spatial Scale in Modern Regional Analysis. Berlin (Springer-Verlag), pp. 45-70. DOI: https://doi.org/10.1007/978-3-642-31994-5_3.

BREZZI, M., PIACENTINI, M., SANCHEZ-SERRA, D. 2015: Measuring Metropolitan Areas: A Comparative Approach in OECD Countries. In Vázquez, E. F., Morollon, F. R. eds. Defining the Spatial Scale in Modern Regional Analysis. Berlin (Springer), pp.71-89.

ČERMÁK, Z., HAMPL, M., MÜLLER, J. 2009: Současné tendence vývoje obyvatelstva metropolitních areálů v Česku: dochází k významnému obratu? Geografie, 114(1), 37-51.

COX, K. 1995: Globalization, Competition and the Politics of Local Economy Development. Urban Studies, 32(2), 213-224. DOI: https://doi.org/10.1080/00420989550013059.

DOSTÁL, P., HAMPL, M. 2002: Metropolitan areas in transformation of regional organisation in the Czech Republic. Acta Universitatis Carolinae Geographica, 37(2), 133-155.

DRUMMOND, L. B. W., YOUNG, D. eds. 2020: Socialist and Post-Socialist Urbanisms. Critical Reflections from a Global Perspective. Toronto (University of Toronto Press).

EC-OECD 2012: Cities in Europe the new OECD-EC definition.Retrieved from: https://ec.europa.eu/regional_policy/sources/docgener/focus/2012_01_city.pdf.

GEMACA 1996: North-West European Metropolitan Regions. Geographical Boundaries and Economic Structures. Paris (GEMACA).

GEMACA 2002: The Metropolises of North-West Europe in Figures. Paris (IAU).

GIBSON, C. 1987: The population in large urban concentrations in the United States, 17901980: a delineation using highly urbanized counties. Demography, 24(4), 601-614. DOI: https://doi.org/10.2307/2061395.

GROTH, J., CORIJN, E. 2005: Reclaiming urbanity: Indeterminate spaces, Informal Actors and Urban Agenda Setting. Urban Studies, 42(3), 503-526. DOI: https://doi.org/10.1080/ 00420980500035436.

HALL, P. 2007: Delineating Urban Territories: Is this a Relevant Issue? In Cattan, N. ed. Cities and Network in Europe. A Critical Approach of Polycentrism. Montrouge (John Libbey Eurotext), pp. 3-14.

HAMPL, M., GARDAVSKÝ, V., KÜHNL, K. 1987: Regionálni struktura a vývoj systému osidleni C $S R$ (1. vydání). Praha (Univerzita Karlova).

HAMPL, M., MÜLLER, J. 1996: Komplexní organizace systému osídlení. In Hampl, M. et al. eds. Geografická organizace společnosti a transformační procesy v České republice. Praha (Př́rodovědecká· fakulta Univerzity Karlovy), 53-89.

HARLOE, M. 2008: Cities in the transition. In Andrusz, G., Harloe, M., Szelenyi, I. eds. Cities after socialism - Urban and regional change and conflict in post-socialist societies. Oxford (Wiley-Blackwell), pp. 1-29.

HARRISON, J., HOYLER, M. 2014: Governing the new metropolis. Urban Studies, 51(11), 2249-2266. DOI: https://doi.org/10.1177/0042098013500699. 
HEEG, S, KLAGGE, B., OßENBRÜGGE, J. 2003: Metropolitan Cooperation in Europe: Theoretical Issues and Perspectives for Urban Networking. European Planning Studies, 11(2), 139-153. DOI: https://doi.org/10.1080/0965431032000072846.

JACOBS, A. J. 2013. The Bratislava metropolitan region. Cities, 31, 507-514. DOI: https://doi.org/ 10.1016/j.cities.2011.10.003.

KATZ, B. ed. 2000: Reflections on Regionalism. Washington DC (Brookings Institution Press).

KEBZA, M. 2018: The development of peripheral areas: The case of West Pomeranian Voivodeship, Poland. Moravian Geographical Reports, 26(1), 69-81. DOI: https://doi.org/ 10.2478/mgr-2018-0006.

KLAPKA, P., HALÁS, M., NETRDOVÁ P., NOSEK, M. 2016: The efficiency of areal units in spatial analysis: Assessing the performance of functional and administrative regions. $\mathrm{Mo}$ ravian Geographical Reports, 24(2), 47-59. DOI: https://doi.org/10.1515/mgr-2016-0010.

KLOK, P. J. 1995: A Classification of Instruments for Environmental Policy. In Dente, B. ed. Environmental policy in Search of New Instruments. Heidelberg (Springer), pp. 21-36. DOI: https://doi.org/10.1007/978-94-015-8504-0_2.

KLOOSTERMAN, R. C., MUSTERD, S. 2001: The polycentric urban region: towards a research agenda. Urban Studies, 38(4), 623-633. DOI: https://doi.org/10.1080/00420980120035259.

KOSTELECKÝ, T., ČERMÁK, D. 2004: Metropolitan areas in the Czech Republic - Definitions, Basic Characteristics, Patterns of Suburbanisation and Their Impact on Political Behaviour. Praha (Sociologický ústav Akademie věd České republiky).

KUNC, J., ŠAŠINKA, P., TONEV, P., DVOŘÁK, Z. et al. 2020: Možnosti metropolitní meziobecní spolupráce a její institucionalizace: prŕíklad Brněnské metropolitní oblasti. Urbanismus a územní rozvoj, 23(6), 23-30.

KUNC, J., TONEV, P., MARTINÁT, S., FRANTÁL, B. et al. 2018: Industrial legacy towards brownfields: historical and current specifics, territorial differences (Czech Republic). Geographia Cassoviensis, 12(1), 76-91.

LANG, T. 2015: Socio-economic and political responses to regional polarisation and sociospatial peripheralisation in Central and Eastern Europe: a research agenda. Hungarian Geographical Bulletin, 64(3), 171-185. DOI: https://doi.org/10.15201/hungeobull.64.3.2.

MIKUŁA, Ł., KACZMAREK, T. 2017: Metropolitan integration in Poland: the case of Poznań Metropolis. International Planning Studies, 22(1), 30-43. DOI: https://doi.org/ 10.1080/13563475.2016.1256191.

MMR ČR 2021: Územni dimenze. ITI. Prague (Ministry of Regional Development of the Czech Republic).

MULÍČEK, O., SEIDENGLANZ, D., FRANKE, D., MALÝ, J. 2013: Vymezení funkčního území Brněnské metropolitní oblasti a Jihlavské sídelní aglomerace. Datový portál města Brna. Retrieved from: https://data.brno.cz/documents/71c042f8a4fb46508e37d738296198f2/explore.

MUSIL, J. 2003: Proměny urbánní sociologie ve Spojených státech a v Evropě 1950-2000. Sociologický časopis, 39(2), 137-167.

ÖIR 2006: The Role of Small and Medium-sized Towns. Final Report of the ESPON Project 1.4.1. European Spatial Planning Observation Network. Retrieved from: https://www.espon.eu/programme/projects/espon-2006/role-small-and-medium-sized-towns.

OSTROM, E. 2010: Beyond Markets and States: Polycentric Governance of Complex Economic Systems. American Economic Review, 100(3), 641-72. DOI: https://doi.org/10.1257/aer.100.3.641.

OUŘEDNÍČEK, M., NEMEŠKAL, J., POSPÍŠILOVÁ, L. 2020: Vymezení území pro Integrované teritoriální investice (ITI) v ČR. Závěrečný dokument. Official Website of Ministry for Regional Development of the Czech Republic. Retrieved from: https://mmr.cz/getmedia/420ae22b-fe354b75-88d0-5824612a4e85/PrF_200120_zaverecny-dokument_final_02042020.pdf.aspx?ext=.pdf. 
PAASI, A. 2002: Regional transformation in the European Context: Notes on Regions, Boundaries and Identity. Space and Polity, 6(2), 197-201. DOI: https://doi.org/10.1080/1356257022000003626.

PAASI, A. 2012: Regional Planning and the Mobilization of 'Regional Identity': From Bounded Spaces to Relational Complexity. Regional Studies, 47(8), 1206-1219. DOI: https://doi.org/ 10.1080/00343404.2012.661410.

SALET, W., THORNLEY, A. 2007: Institutional Influences on the Integration of Multilevel Governance and Spatial Policy in European City-Regions. Journal of Planning Education and Research, 27(2), 188-198. DOI: https://doi.org/10.1177/0739456X07307207.

STANILOV, K. ed. 2007: The Post-Socialist City. Urban Form and Space Transformations in Central and Eastern Europe after Socialism. Dordrecht (Springer).

SÝKORA, L., MULÍČEK, O. 2009: The Micro-regional Nature of Functional Urban Areas (FUAs): Lessons from the Analysis of the Czech Urban and Regional System. Urban Research \& Practice, 2(3), 287-307. DOI: https://doi.org/10.1080/17535060903319228.

ŠAŠINKA, P., KUNC, J., FRANTÁL, B., DVOŘÁK, Z. 2019: Cooperation differs. Intentions of municipalities towards metropolitan cooperation in post-socialist space - Brno, Czech Republic. European Planning Studies, 27(4), 818-840. DOI: https://doi.org/10.1080/09654313.2019.1569597.

ŠAŠINKA, P., ZVARA, J. 2014: Institutionalization of metropolitan areas as possible solution of agglomeration externalities in the context of urbanization development in the Czech Republic. Acta Universitatis Agriculturae et Silviculturae Mendelianae Brunensis, 62(6), 1451-1463. DOI: http://dx.doi.org/10.11118/actaun201462061451.

ŠILHAN, Z., KUNC, J. 2020: Two decades of changes in spatial distribution of retail and commercial services: Czech experience. Hungarian Geographical Bulletin, 69(1), 41-55. DOI: https://doi.org/10.15201/hungeobull.69.1.4.

ŠVEDA, M., MADAJOVÁ, M., PODOLÁK, P. 2016. Behind the Differentiation of Suburban Development in the Hinterland of Bratislava, Slovakia. Sociologický časopis / Czech Sociological Review, 52(6), 893-925. DOI: http://dx.doi.org/10.13060/00380288.2016.52.6.2.

TONEV, P., DVOŘÁK, Z., ŠAŠINKA, P., KUNC, J. et al. 2017: Different approaches to defining metropolitan areas (Case study: cities of Brno and Ostrava, Czech Republic). Geographia Technica, 12(1), 108-120. DOI: https://doi.org/10.21163/GT_2017.121.11.

TÖRÖK, I. 2015: City Region and Socio-Spatial Polarization in Romania. Procedia Earth and Planetary Science 15, 951-955. DOI: https://doi.org/10.1016/j.proeps.2015.08.152.

TOSICS, I. 2005: City development in Central and Eastern Europe since 1990: The impacts of internal forces. In Hamilton F. E. I., Andrews, K. D. and Pichler-Milanovic, N. eds. Transformation of Cities in Central and Eastern Europe: Towards Globalization. New York (United Nations University Press), pp. 44-78.

VITURKA, M., PAŘIL, V., TONEV, P., ŠAŠINKA, P., KUNC, J. 2017: The metropolisation processes: A case of Central Europe and the Czech Republic. Prague Economic Papers, 26(5), 505-522. DOI: https://doi.org/10.18267/j.pep.624.

WILKS-HEEG, S., PERRY, B., HARDING A. 2002: Metropolitan Regions in the Face of the European Dimension: Regimes, Re-scaling or Repositioning? In Kreukels, A., Salet W. and Thornley A. eds. Metropolitan Governance and Spatial Planning ( $1^{\text {st }}$ edition). London (Routledge), pp. 20-38. DOI: https://doi.org/10.4324/9780203986493.

ŽENKA, J., SLACH, O., SOPKULIAK, A. 2017: Typologie českých nemetropolitních regionů z hlediska faktorů, mechanismů a aktérů regionálního rozvoje. Geografie, 122(3), 281-309.

\footnotetext{
Acknowledgement:

This study was supported by TAČR ÉTA (TL03000230) project: Institutionalization of metropolitan cooperation as a factor of increasing the motivation of municipalities to cooperate in metropolitan areas.
} 


\section{Authors' affiliations}

\section{Josef Kunc}

Department of Regional Economics and Administration

Faculty of Economics and Administration, Masaryk University

Lipová 41a, 60200 Brno

Czech Republic

josef.kunc@econ.muni.cz

\section{Petr Tonev}

Department of Regional Economics and Administration

Faculty of Economics and Administration, Masaryk University Lipová 41a, 60200 Brno

Czech Republic

petr.tonev@econ.muni.cz

\section{Markéta Novotná}

Department of Regional Economics and Administration

Faculty of Economics and Administration, Masaryk University

Lipová 41a, 60200 Brno

Czech Republic

marketa.novotna@econ.muni.cz

\section{Petr Šašinka}

Department of Regional Economics and Administration

Faculty of Economics and Administration, Masaryk University Lipová 41a, 60200 Brno

Czech Republic

sasinka.petr@brno.cz

\section{Zdeněk Dvořák}

Department of Regional Economics and Administration

Faculty of Economics and Administration, Masaryk University

Lipová 41a, 60200 Brno

Czech Republic

dvorak.zdenek@brno.cz

\section{Soňa Raszková}

Department of Regional Economics and Administration

Faculty of Economics and Administration, Masaryk University

Lipová 41a, 60200 Brno

Czech Republic

raszkova.sona@brno.cz

\section{Aneta Krajíčková}

Department of Regional Economics and Administration

Faculty of Economics and Administration, Masaryk University

Lipová 41a, 60200 Brno

Czech Republic

aneta.krajickova@mail.muni.cz 